\title{
BUILDING QUALITY OF HUMAN RESOURCES THROUGH JOB SKILL BASED ON LOCAL WISDOM OF "PAGEH, PUGUH, LAN JENGAH" AT VILLAGE CREDIT INSTITUTIONS (LPD) OF BULELENG REGENCY
}

\author{
Luh Kartika Ningsih ${ }^{1}$, Ni Luh Putu Eka Yudi Prastiwi ${ }^{2}$, \\ Management, STIE Satya Dharma Singaraja, Indonesia \\ luhkartikaningsih@gmail.com ${ }^{1}$
}

\begin{abstract}
The purpose of the research was to determine how to build quality of human resources through job skill based on "Pageh, Puguh, lan Jengah" at the Village Credit Institute (LPD) in Buleleng Regency. Through testing several relationships to determine the improvement in the quality of human resources in the LPD.This research used a quantitative approach. The data analysis technique used was Structural Equation Modeling-SEM) variance-based or component based SEM, called Partial Least Square (PLS) Visual version 3.0. The sample used 60 people with a t-table value for a significant level of $\alpha=0.05$ of 1.96. All of the relationships showed positive and significant results. From the results of this research it is known that through the implementation of job skill based on "Pageh, Puguh, lan Jengah" is able to improve the quality of human resources that impacts on improving the performance of the employee in LPD of Buleleng Regency.
\end{abstract}

Keywords: Job Skill based on "Pageh, Puguh, lan Jengah"; Job Achievement; Employee Performance.

\section{INTRODUCTION}

Human Resources are the key to growing an organization. Tohardi (2002) gives the meaning of human resources all the potential in humans, both in the form of reason, thoughts, energy, skills, emotions, and so on, which are used for self or individual interests and for common interests in realizing organizational goals. Judging from the position and role of human resources in the development of an organization, Human Resources has 3 (three) positions and roles. First is the position and role as a human being who works in a certain environment, the second is as a human being who is in a position and acts as a driving force for the organization to realize its existence. Third, as assets whose value cannot be calculated as with capital. Even in the position and role as an asset of an organization, human resources can be a determining factor in delivering the achievement of organizational goals (Astawa, 2009). Building quality human resources is very important to the success of achieving organizational goals. Therefore, it is important to pay attention to the strategies that must be carried out as an effort to improve the quality of human resources. This condition is supported by Achmad's (2016) research regarding employee performance, which shows 
positive results influenced by several variables including competence, motivation, and organizational culture.

It is also in the current conditions of Human Resources that are far from being able to acquire the skills that will be used in trying to develop organization. Especially the Village Credit Institution (LPD) in Buleleng Regency. In fact, not a few LPD employees still have limited ability to carry out their duties and responsibilities. Both from limited knowledge about technology or skills possessed by each individual in completing his duties and responsibilities. In the Hindu concept, Balinese people have local wisdom which is used as a guide in carrying out daily life, in society, and carrying out their work. In the view of traditional Balinese society, what is called work ethic has become a habit and has been embedded for a long time. From this phenomenon, researchers are interested in conducting research related to improving quality of human resources through job skill based on local wisdom, namely "Pageh, Puguh, lan Jengah". This combination is an idea to find out when modern elements are mixed with traditional elements / local wisdom can show good results or vice versa.

A previous study conducted by Febrio (2019) in their research entitled "The Effect of Skill, Experience and the Work Environment on Employee Performance", had no significant result related to the influence of Job Skill on Employee Performance at PT. Tri Mustika Cocominaesa (South Minahasa). These results indicate that there are still many employees who do not yet have sufficient skills in carrying out their duties and responsibilities, it is evident from the low level of skills that have an effect on the performance of employees. In this study, the research conducted about Job Skills based on local wisdom of "Pageh, Puguh, lan Jengah" through some researched relationships, as an effort to build quality of Human Resources by improving job achievement and employee performance in LPD of Buleleng Regency.

\section{Job Skill}

Sofyang (2017) states that skills are the ability to translate knowledge into practice to achieve the desired goals. The most important skills are those that allow managers to help others become more productive in the workplace. Skills are a very complementary relationship in that the form of people who have competence is reflected in the level of skills they have. A skilled person will show a level of independence in work, reliable in completing work and professional (expert) in the field he/she is engaged in, in accordance with the training produced from fundamental employees with quality requirements. Of course, these skills are a part of a person's competence that can be assessed.

Wahyudi (2002) defines skills as skills or expertise to do a job only obtained in practice. Irianto (2015) states that skills are related to one's expertise to do something that is tangible. Besides physical, the meaning of skill also refers to a person's mental, manual, motor, perceptual and even social abilities. It can be concluded that skill is the ability to do something that is done quickly, well, and precisely. Skills can be seen by the achievement of employee performance in carrying out the duties and responsibilities in a company organization. Skills are also a skill or skill possessed by employees in doing work that is obtained through practice, both training and through experience.

Skills are an important aspect that had by the employees at work. According 
to Mangkunegara (2010) job skills can be assessed through the following assessment indicators:

a. Perception, including object interpretation, stimulus reception, stimulus organization, stimulus interpretation;

b. Self-control, including attitudes, emotions and motives;

c. Carry out collective responsibility, carried out jointly with colleagues;

d. Carry out individual responsibilities, carried out in accordance with the abilities and areas of expertise of individual employees.

\section{Job Skill Local Wisdom-based "Pageh, Puguh, lan Jengah"}

In the Balinese language dictionary, Pageh means strong heart or stay royal (Kersten, 1984). Meanwhile, Puguh means serious or concentrated on work, duties and responsibilities, while Jengah is defined as a condition that encourages people to cause embarrassment if nothing is done to him or others or society. If it is in harmony with the viewpoint of modern society it can be explained again that:

a. Pageh, means loving work, duties, and responsibilities

b. Puguh, means having a high work ethic

c. Jengah, means having a strong motivation to grow and develop (Astawa, 2009)

In the view of traditional Balinese society, Pageh, Puguh, lan Jengah is a view of a desire to be able to provide positive and productive things by loving work and responsibilities and being able to achieve goals that are currently being worked on with a high work ethic. This is done because you feel motivated and get support to give something to yourself and others.

\section{Job Achievement}

According to Byars and Rue in Sutrisno (2016) Job Achievement is a person's level of proficiency in tasks that include work. This definition shows the weight of an individual's ability to fulfill the conditions in his job. According to Mangkunegara (2017:67), job achievement is the result of work in quality and quantity achieved by an employee in carrying out his duties according to the responsibilities assigned to him.

The job achievement's indicators according to Sutrisno (2016) are as follows:

a. Job results, the level of quantity and quality that has been produced and the extent to which supervision is carried out.

b. Job knowledge, the level of knowledge associated with work tasks that will directly affect the quantity of job results.

c. Initiative, the level of initiative during carrying out work tasks, especially in terms of handling problems that arise.

d. Mental dexterity, the level of ability and speed in receiving work instructions and adjusting to the way of working and the existing work situation.

e. Attitude, level of morale and positive attitude in carrying out work tasks.

f. Discipline in time and attendance, punctuality level and attendance level

\section{Employee Performance}

According to Osborn (1991), said that performance is: "As the quality and quantity of the achievement of tasks, whether carried out by individuals, groups or companies". Meanwhile, according to Tika (2006), performance results from the work/activity of a person or group in an organization that is influenced by various factors to achieve organizational goals within a certain period of time.

Bernardin \& Russel (2003) state that to measure employee performance, 
several performance indicators can be used, including:

a. Quality is the level where the process or result of completing an activity is close to perfect.

b. Quantity is the product produced and can be shown in units of currency, number of units, or number of cycles of activities completed.

c. Timeliness is where the activity can be completed, or a production result can be achieved, at the beginning of the determined time together with coordination with other product results and maximizing the time available for other activities.

d. Cost effectiveness is the degree to which organizational resources, such as human, financial, technology, and raw materials can be maximized in the sense of obtaining the highest profit or reducing losses arising from each unit or example of the use of an existing resource.

e. Interpersonal impact is the level at which an employee is able to develop feelings of mutual respect, goodwill and cooperation between one employee and another and also to subordinates.

\section{Previous Research}

In accordance with the background description and literature review that has been presented above, this research is also based on several previous studies with the same research, including research conducted by Togas \& Uhing (2015) where the results of research show that Job Skill have a positive effect. and significant to Job Achievement. Furthermore, Sofyang (2017) from the results of their research which examined Job Skill had no significant effect on employee performance. Likewise, research conducted by Winarni et al. (2016) which examines Job Achievement on Employee Performance has a positive and significant effect.

The results of this study form the basis for the preparation of research concepts that are proposed and tried to be developed and researched at the Village Credit Institution (LPD) in Buleleng Regency, so the following framework can be formed:

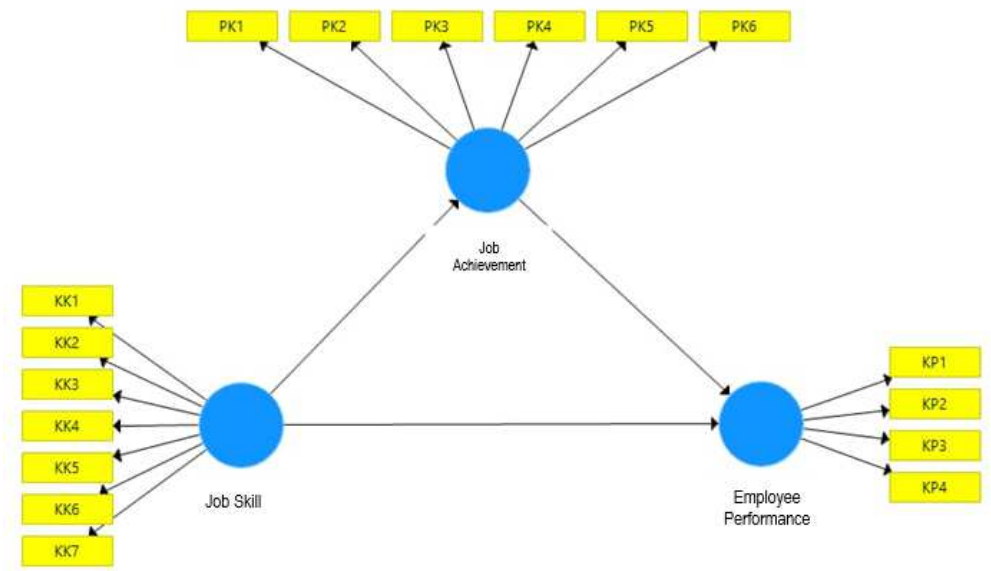

Figure 1. Framework

\section{METHODOLOGY}

This research is explanatory in the form of causality between variables. In this study, the relationship between Job Skills based on local wisdom "Pageh, Puguh, lan Jengah, Job Achievement, and Employee Performance in LPDs in Buleleng 
Regency. The development of a model in this study attempts to predict the causality relationship between variables. This is to determine the effect of job skills based on local wisdom in the LPD. The research location was carried out at the Village Credit Institution (LPD) in Buleleng Regency. The sample used in this research was 60 LPDs out of 142 total populations spread across Buleleng Regency.

The research instrument used was a questionnaire as a data collection tool. Of the 60 questionnaires distributed, all questionnaires have been returned and filled out completely. The collected data were analyzed using variance-based (Structural Equation Modeling-SEM) or Component based SEM, which is known as Partial Least Square (PLS) Visual version 3.0.

\section{RESULTS AND DISCUSSION \\ Assessing the Output Model or Measurement Model}

In testing the validity of the outer model, two factors observed in the validity test, namely the cross-loading factor (convergent validity) and the cross loading value (discriminant validity). Convergent validity measures the correlation between the question items and the construct in the study. Individual reflexive measures were said to be correlated more than 0.7 with the construct desired to be measured. However, for a preliminary research stage of developing a scale, the measurement of the leveling factor 0.6 is considered sufficient (Ghozali, 2008). At the initial stage, data testing is carried out to determine the level of accuracy of the indicators in explaining the exogenous construct in the model using the loading factor. Based on the path diagram of the research model, the results are shown in Figure 2

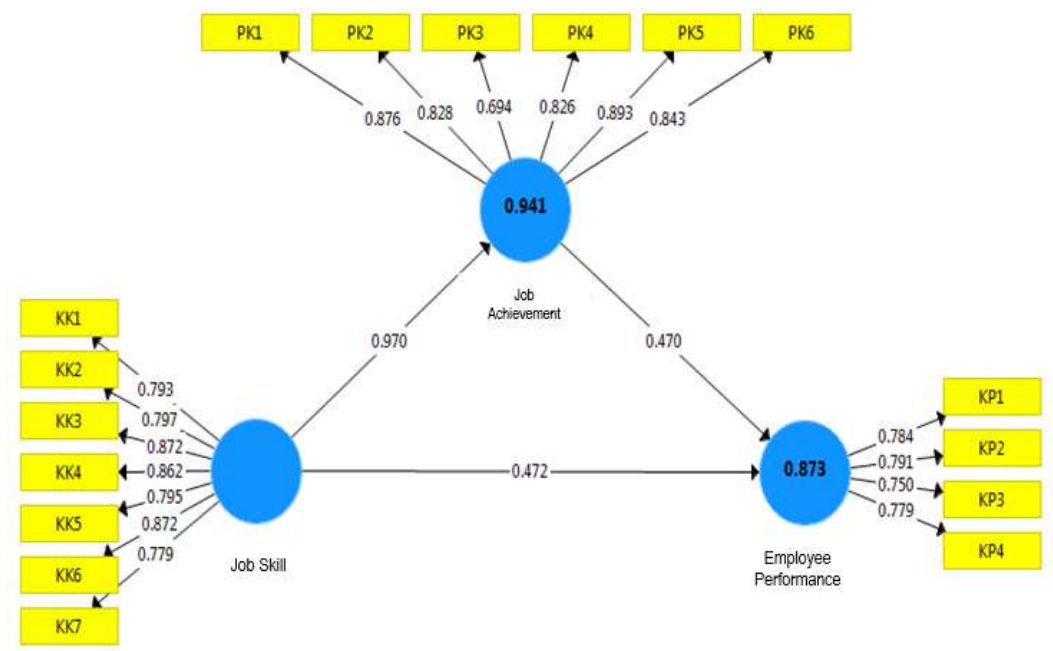

Figure 2. Score of Loading Factor

Based on the picture above, the loading factor value shows the results that meet the convergent validity because all loading factors are $>0.6$. Thus, it can be concluded that the convergent validity of all constructs is valid. To strengthen the valid statement of the construct of this study, researchers also used the Average Variance Extracted (AVE) method. A good construct requires that the AVE value must be above 0.50 . The AVE test results are described as follows: 
Table 1. Average Variance Extracted (AVE) Value

Average Variance Extracted (AVE)

\begin{tabular}{|c|c|}
\hline $\begin{array}{l}\text { Job Skill Based "Pageh, } \\
\text { Puguh, lan jengah" }\end{array}$ & 0.681 \\
\hline Employee Performance & 0.603 \\
\hline Job Achievement & 0.688 \\
\hline
\end{tabular}

From the table above it can be seen that all constructs meet the minimum requirements for AVE value $>0.5$, it can be concluded that all constructs in this study are valid.

Furthermore, reliability can be seen from the value of Composite Reliability (CR) and Cronbach's Alpha. The construct is said to have high reliability if the Composite Reliability value is above 0.70 and the Cronbach's Alpha value is above 0.60 (Ghozali, 2008). In table 2, the values of Composite Reliability and Cronbach's Alpha are presented for all variables.

\begin{tabular}{lcc}
\multicolumn{3}{c}{ Table 2. Composite Reliability dan Cronbach's Alpha Value } \\
\hline & $\begin{array}{c}\text { Cronbach's } \\
\text { Alpha } \\
>0,60\end{array}$ & $\begin{array}{c}\text { Composite } \\
\text { Reliability } \\
>0,70\end{array}$ \\
\hline $\begin{array}{l}\text { Job Skill Based "Pageh, Puguh, lan } \\
\text { jengah" }\end{array}$ & 0.921 & 0.937 \\
\hline Employee Performance & 0.782 & 0.858 \\
\hline Job Achievement & 0.908 & 0.929
\end{tabular}

Source: Data processed

The table above shows that all the constructs in this study resulted in Composite Reliability value above 0.70 and Cronbach's Alpha value above 0.60 . It can be concluded that the construct in this study is reliable.

Structural Model Testing (Inner Model)

In assessing the model with PLS, it starts by looking at the R-square for each dependent latent variable (Ghozali, 2008). Table 3 is the result of R-square estimation using SmartPLS.

Table 3. R-Square Value

\begin{tabular}{lc}
\hline & R-Square \\
\hline Employee Performance & 0.873 \\
\hline Job Achievement & 0.941 \\
\hline \multicolumn{2}{c}{ Source: Data processed }
\end{tabular}

The model influence job skill based on local wisdom "Pageh, Puguh, lan Jengah" on Employee Performance gives r-square value of 0.873 which can be 
interpreted that the constructed variabilities of employee performance can be explained by constructed of job skill based on local wisdom "Pageh, Puguh, lan jengah" of $87.3 \%$ while $12.7 \%$ is explained by other variables that are not studied. Furthermore, the job skills influence model based on local wisdom "Pageh, Puguh, lan jengah" toward job achievement gives r-square value of 0.941 which can be interpreted that the construct of Job Skill can explain the constructed variabilities of Job Achievement based on local wisdom "Pageh, Puguh, lan jengah" by $94.1 \%$ while $5.9 \%$ is explained by other variables that are not studied

\section{Hypothesis Testing}

The basis used in testing the hypothesis is the value contained in the output result for inner weight. Table 4 provides the estimated output for testing the structural model.

Table 4. Result for Inner Weight

\begin{tabular}{lccccc}
\hline & $\begin{array}{c}\text { Original } \\
\text { Sample } \\
(\mathrm{O})\end{array}$ & $\begin{array}{c}\text { Sample } \\
\text { Mean } \\
(\mathrm{M})\end{array}$ & $\begin{array}{c}\text { Standard } \\
\text { Deviation } \\
(\text { STDEV })\end{array}$ & $\begin{array}{c}\text { T Statistics } \\
(|\mathrm{O} / \mathrm{STDEV}|) \\
>1,96\end{array}$ & $\begin{array}{c}\text { Significance } \\
\text { Test }\end{array}$ \\
\hline $\begin{array}{l}\text { Job Skill based "Pageh, } \\
\begin{array}{l}\text { Puguh, lan Jengah" -> } \\
\text { Employee Performance }\end{array}\end{array}$ & 0.927 & 0.930 & 0.015 & 60.495 & Significant \\
\hline $\begin{array}{l}\text { Job Skill based "Pageh, } \\
\begin{array}{l}\text { Puguh, lan Jengah" }-> \\
\text { Job achievement }\end{array}\end{array}$ & 0.970 & 0.971 & 0.007 & 148.881 & Significant \\
\hline $\begin{array}{l}\text { Job Achievement-> } \\
\text { Employee Performance }\end{array}$ & 0.470 & 0.491 & 0.186 & 2.532 & Significant \\
\hline
\end{tabular}

Source: Data Processed

And the following is the estimated output for testing the structural model which is shown in the form of Figure 3 below:

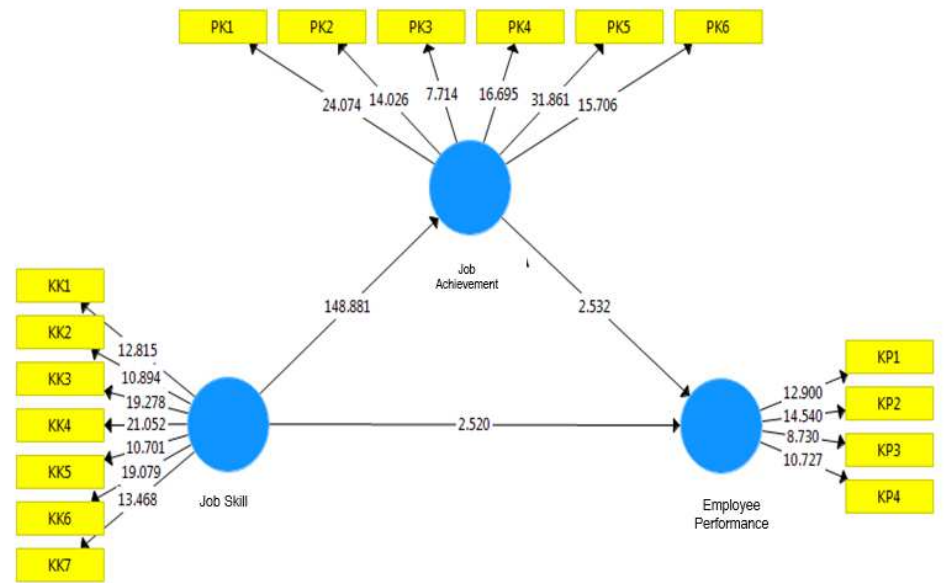

Figure 3. Score of Bootstrapping

From the data above, it can be seen that the results of the first hypothesis testing show the relationship of Job Skill based on local wisdom "Pageh, Puguh, lan Jengah" toward Performance Achievement, indicating the highest level of 
significance. With a parameter coefficient of 0.927 and a t-statistic value of 148.881. This result means that Job Skills based on local wisdom "Pageh, Puguh, lan Jengah" have a positive and significant effect on Job Achievement. Hypothesis 1 is accepted. The better Job Skill based on local wisdom "Pageh, Puguh, lan Jengah", the better employee performance in LPDs in Buleleng Regency. From the results of the research, it can be seen that the awareness of LPD employees in carrying out the tasks is very high, it can be seen from the variable of Job Skill based on local wisdom "Pageh, Puguh, lan Jengah" where modern elements are combined with more traditional elements as local wisdom, then it has been a habit of practicing for a long time. Furthermore, this reflects the trust exercised by the local community, especially employees in each LPD. The high level of significance in this relationship shows that every LPD employee has the awareness to provide good performance, pageh (still loyal), strong (serious and concentrated on work), embarrassed (motivated), this helps LPD employees to interpret LPD to work well and achieve maximum LPD performance.

The second hypothesis test results show that the Job Skill based on local wisdom "Pageh, Puguh, lan Jengah" toward employee performance shows the value of the parameter coefficient of 0.927 and the t-statistic value 60.495. This result means that Job Skills based on local wisdom "Pageh, Puguh, lan Jengah" have a positive and significant effect on employee performance. The 2 nd hypothesis is accepted. The better Job Skill based on local wisdom "Pageh, Puguh, lan Jengah", the better employee performance in the LPDs in Buleleng Regency. The high level of awareness of LPD employees in improving employee performance is indicated by the seriousness of carrying out their duties and responsibilities. This is also supported by a good understanding of the concept of "Pageh, Puguh, lan Jengah" which have become habits and norms that must be adhered to firmly to be able to carry out every job.

The 3rd hypothesis test results showed that the relationship between Job Achievement to Employee Performance showed a parameter coefficient value of 0.470 and a t-statistical value of 2,352. These results mean that Job Achievement has a positive and significant impact on employee performance. The $3 \mathrm{rd}$ hypothesis is accepted. The better the performance of the work, the better the performance of employees in LPD in Buleleng Regency. The significant level of significance described in this relationship confirms that every application in LPD is able to maximize the success of the work it has. This is often conducted when LPD employees carry out both formal and non-formal work. The formal activity in question is the work activity in LPD, while informal activities are rural activities that involve LPD role in its implementation such as ngaben massal activities, tirta yatra, and other activities carried out in the village. The pattern of work that has been based on the concept of "Pageh, Puguh, lan Jengah", his side job is done seriously so that this is able to have a positive impact on the improvement of the quality of employee performance of LPD in Buleleng Regency.

\section{CONCLUSION}

From the results of the research, it is known that the local wisdom in the life of the Balinese people, especially at the Village Credit Institution (LPD) in the Buleleng Regency has become a work ethic and a habit that is often practiced in social life, but it cannot be interpreted perfectly and is just walking around in 
moderation. However, when these traditional elements are combined with modern elements, the LPD apparatus makes it easier to interpret the meaning of a job skill to be able to improve one's own quality from a local wisdom concept "Pageh, Puguh, lan Jengah".

Researchers realize that this research is still very far from perfect, therefore, for further research, it can be re-tested related to Job Skills at Village Credit Institutions (LPD) and is able to develop more complex research relationships to ensure successful results and can be used as a reference for LPD servants.

\section{REFERENCES}

Achmad, N. (2016). Metodologi Penelitian Bisnis. Fakultas Ekonomi dan Bisnis Universitas Muhammadiyah Surakarta.

Astawa, I. N. D. (2009). Kearifan Lokal dan Pembangunan Ekonomi. Pustaka Larasan.

Bernardin, H. J., \& Russel, J. E. . (2003). Human resource management (An Experimental Approach International Editio). Singapore.

Febrio, L. (2019). Pengaruh Keterampilan, Pengalaman dan Lingkungan Kerja Terhadap Kinerja Karyawan di PT. Tri Mustika Cocominaesa (Minahasa Selatan). Jurnal EMBA, 7(1), 281 - 290.

Ghozali, I. (2008). Structural Equation Modeling Metode Alternatif dengan Partial Least Square (2 ed.). Badan Penerbit Universitas Diponegoro.

Irianto, K. (2015). Memahami Berbagai Macam Penyakit. Alfabeta.

Kersten, S. V. D. (1984). Bahasa Bali. Nusa Indah.

Mangkunegara, A. P. (2010). Perilaku dan Budaya Organisasi. Refika Aditama.

Mangkunegara, A. P. (2017). Manajemen Sumber Daya Manusia. Remaja Rosdakarya Offset.

Osborn, M. P. (1991). Breast Development and Anatomy. In J. R. Harris (Ed.), Breast Disease (2 ed.). J.B. Lippincot-Raven.

Sofyang. (2017). Pengaruh Motivasi, Lingkungan Kerja dan Keterampilan terhadap Kinerja Pegawai Pada Kantor Dinas Pendapatan Pengelolaan Keuangan Dan Aset Daerah Kabupaten Soppeng. Jurnal Mirai Management, 2(1), 70-90.

Sutrisno, E. (2016). Manajemen Sumber Daya Manusia. Kencana Prenada Media Group.

Tika, M. P. (2006). Budaya Organisasi dan Peningkatan Kinerja Perusahaan. Bumi Aksara.

Togas, F. B., \& Uhing, Y. (2015). Pengaruh Lingkungan Kerja, Motivasi, dan Keterampilan terhadap Prestasi Kerja Karyawan Pada Bank BRI Cabang Manado. Jurnal EMBA, 3(3), 1162-1173.

Tohardi, A. (2002). Manajemen Sumber Daya Manusia. Mandar Maju.

Wahyudi, B. (2002). Manajemen Sumber Daya Manusia. Sulita.

Winarni, R., Muhtadi, A., \& Surahman, E. (2016). Pengaruh Penilaian Prestasi Kerja dan Kompensasi terhadap Kinerja Tenaga Teknis Kefarmasian Non-PNS Instalasi Farmasi RSUP Dr. Hasan Sadikin. Jurnal Farmasi Klinik Indonesia, 5(4), 278-287. 